\title{
Saving camels from straws: how propagule pressure-based prevention policies can reduce the risk of biological invasion
}

\author{
Jamie K. Reaser · Laura A. Meyerson • \\ Betsy Von Holle
}

Received: 18 October 2007 / Accepted: 19 October 2007 / Published online: 3 November 2007

(C) Springer Science+Business Media B.V. 2007

\begin{abstract}
Nonnative species that harm or have the potential to cause harm to the environment, economy, or human health are known as invasive species. Propagule pressure may be the most important factor in establishment success of nonnative species of various taxa in a variety of ecosystems worldwide, and strong evidence is emerging that propagule pressure determines both the scale of invasion extent
\end{abstract}

The views expressed in this paper are solely those of the authors and do not necessarily reflect those of the US government.

\section{J. K. Reaser ( $\square)$}

Ecos Systems Institute, c/o Ravens Ridge Farm, 1207 Bull Yearling Road, Stanardsville, VA 22973, USA

e-mail: ecos@nelsoncable.com

\section{A. Meyerson}

Department of Natural Resources Science, University of Rhode Island, 1 Greenhouse Road, Kingston, RI 02881, USA

e-mail: Laura_Meyerson@uri.edu

\section{B. Von Holle}

National Center for Environmental Assessment, Office of Research and Development (8623-D), U.S. Environmental Protection Agency, Washington, DC, USA e-mail:

\section{Present Address:}

B. Von Holle

Department of Biology, University of Central Florida, 4000 Central Florida Blvd, Orlando, FL 32816-2368, USA and impact. In a limited way, the US government is applying a "propagule pressure approach" in a variety of prevention policy contexts aimed at minimizing the impact of harmful organisms. However, there are also readily apparent opportunities for enacting propagule pressure-based measures to fill current gaps in invasive species prevention and control at national, state, and local levels. An explicit focus on propagule pressure-based policies could substantially increase the effectiveness of US efforts to prevent the introduction of invasive species through by intentional and unintentional introductions.

Keywords Invasive species - Policy ·

Prevention · Propagule pressure · United States

"As the last straw breaks the laden camel's back..." -Charles Dickens, Dombey and Son

\section{Introduction}

Imagine a camel standing next to a large pile of straw. Calculate the maximum number of straws you can place on the camel, one at a time, without breaking its back. Got the answer?

Although the addition of a single straw could eventually push the camel's back beyond its stability threshold, numerous variables must be considered in order to determine how much is too much: How old is the camel? How big? How's its health? Any history 
of back problems? Is it stationary, walking, or running? Is it carrying anything besides straw? How long is each piece of straw? What is its weight? What parameters define how the straw can be distributed over the camel's body? And so on.

Luckily for the camel, you are able to expertly calculate the load limits and successfully deliver the straw to the next village. Well done.

Unfortunately, the environment, economy, and human health in the United States are not being granted as much respect and scientific know how as the camel. Many government officials are failing to ask "How much is too much?" let alone implement scientifically-based policies to keep the introduction of potentially invasive species below "back-breaking" thresholds.

Nonnative species that harm or have the potential to cause harm to the environment, economy, or human health are known as invasive species (Federal Register 1999; NISC 2001). Invasive species can place constraints on ecosystem processes and services and have significant socio-economic impacts, including impacts on human health and safety. The process of biological invasion can be facilitated by any activity that results in the movement of goods (commodities) and services (including people and equipment) between evolutionarily-isolated ecosystems (Mack et al. 2000; Sala et al. 2000; McNeely et al. 2001).

As a result of the increased rate and scale of global trade and travel, the importation of nonnative species into the United States has been increasing exponentially since 1920 (Levine and D'Antonio 2003). Nonnative species are intentionally imported for use in a broad range of industries (e.g., agriculture, horticulture, medicine, and the pet trade), and inadvertently imported as 'hitchhikers' on a wide variety of internationally traded organisms (e.g., plants and livestock), people (e.g., tourists and their personal affects), non-living goods (e.g., tiles and furniture), and packaging materials (e.g., wood pallets and crates).

Propagule pressure is one of the key factors influencing the rates of establishment and scale of impacts of invasive species. Propagule pressure is a composite measure of the number of individuals released into an ecosystem to which they are not native. It incorporates both number of discrete release events (propagule number) and the absolute number of individuals involved in any one introduction event (propagule size) (Lockwood et al. 2005). Metaphorically speaking, propagule pressure is the number of loads of straw deposited on the back of the camel as well as the number of individual straws in each load. If five piles of straws are loaded on the camel and the number of straws in each pile is 1,398 , $1,415,1,287,1,322,1,497$, respectively, then the propagule pressure of straws to the camel is 6,919 .

Propagule pressure has been assigned special importance in biological invasions (Simberloff 1989; Williamson 1996). Studies of plants (Von Holle and Simberloff 2005) and animals (Beirne 1975; Veltman et al. 1996; Green 1997; Duggan et al. 2006) indicate that the higher the propagule pressure, the greater the probability of successful establishment by the nonnative invader(s). Propagule pressure may be the most important factor in establishment success of nonnative species of various taxa in a variety of ecosystems worldwide (Lonsdale 1999; Fine 2004). Furthermore, strong evidence is emerging that propagule pressure determines both the scale of invasion extent and impact (Lockwood et al. 2005; Von Holle and Simberloff 2005). From the pack camel's perspective, this means that the number of loads of straw and number of straws per load are more likely to influence the stability of its back than are other factors, such as its age, size, or mobility.

Probability models and field studies indicate a direct correlation between propagule pressure and levels of genetic variation within the introduced population (Lockwood et al. 2005; Meyerson and Mooney 2007; Roman and Darling 2007). Thus, high propagule pressure may increase the ability of the introduced organisms to adapt to novel selective pressures and survive in the recipient ecosystem (Lockwood et al. 2005). Additionally, when multiple introductions of individual organisms occur and those organisms originate from different parts of the species' native range, it is possible that the genetic diversity of the introduced population will enable wider range occupation and/or greater range expansion (Parker et al. 2003). For example, the European green crab (Carcinus maenus) did not expand into the northern part of its current introduced range in the eastern United States until populations from Sweden and Norway, which is in the more northern part of its European native range, were introduced (Roman 2006).

Allee affects (i.e., limits on reproductive potential) may diminish as greater numbers of individuals or 
release events occur. At least three, non-independent scenarios are possible: (1) more release events and more individuals increase the probably that at least some of the organisms will be introduced into an environmental situation (e.g., soil type, weather conditions, low competition) in which they can establish, survive, and reproduce; (2) if the introduced species reproduces sexually, the likelihood of finding a mate increases with the number of introduced individuals; and (3) some species can modify environmental conditions in their favor and thus increase reproductive capacity when they occur in larger groupings (Cappuccino 2004).

Interactions between propagule pressure and other environmental factors can further increase the likelihood of invasion success, and the effects may be additive (Meyerson and Mooney 2007). For example, the more an area is disturbed, the easier it is to invade (Crawley 1989; D’Antonio et al. 2001). Climate change will cause ecological disturbances at all scales (Watson et al. 2001) and may thus increase the probability (risk) that a smaller number of propagules and fewer introduction events lead to the establishment and impact of certain invasive species.

In short, the likelihood of a nonnative species establishing in the US and causing harm is strongly influenced by the volume and frequency of individual introduction events. Because propagule pressure is determined by interacting factors of ecological, technical, managerial, socio-economic, and political origin, efforts to minimize the impact of invasive species need be multi-dimensional, simultaneously addressing both the ecological and socio-political drivers of biological invasion. The remainder of this paper will focus on the needs and opportunities for increasing the capacity of the US to prevent invasive species introductions by establishing policies more consistent with the science of propagule pressure. We focus particularly on unintentional introductions, recognizing that propagule pressure based policies for intentional introductions necessitate a different approach and longer time frame, owing to greater capacity building needs within the Federal government and cooperation from affected private sector stakeholders. Nonetheless, it is our contention that greater enactment of propagule pressure-based policies could substantially improve the US's ability to prevent the movement of invasive species across and within its borders for both intentional and unintentional introductions.

\section{A call for improved prevention strategies}

The US government has identified prevention measures (e.g., risk assessments, inspection, quarantine, trade regulations, voluntary codes of conduct, and education) as the most cost-effective means of minimizing the introduction and thus impact of invasive species (NISC 2001; ANSTF 2007). However, historical and current efforts by the US government to minimize the introduction and impact of invasive species are largely focused on reactionary, taxon-specific approaches. Specific nonnative organisms must be taxonomically identified and sufficient evidence must be obtained to prove that they have already caused or have strong potential to cause significant harm to highly valued resources (typically plant and animal-based production systems, endangered species, and/or human health) within the US. This approach requires substantial informational resources, assessment time (ranging from hours to days) by expert pest identifiers, and heavy reliance on the capacity of import inspectors. Studies have revealed that Federal inspection agencies are lacking in some key human and informational capacities (GAO 2006a, b; Reaser and Waugh 2007) and the brisk pace of new invasions indicates that this system is insufficient to meet national needs (Levine and D'Antonio 2003; McCullough et al. 2006).

Recently, inter-departmental bodies have directed the Federal agencies (often in partnership with states, tribes, and other stakeholders) to take specific actions to implement more comprehensive, proactive prevention measures (Table 1). These directives have been echoed within specific agency mandates (e.g., NPB 1999), as well as at international (Table 2) and state levels (Fig. 1). Although the screening process and risk assessment methodologies being developed within the US do not explicitly consider propagule number and size, strategies focused on pathway management (e.g., ideally, eliminating all "hitchhiking" organisms associated with certain commodities, packaging, and conveyances), have the potential to be consistent with propagule pressure theory by reducing the overall pool of propagules available for introduction. 
Table 1 US inter-departmental directives for improved invasive species prevention strategies

Source Examples

United States

National Invasive Species Management Plan (NISC 2001)

Aquatic Nuisance Species Task Force (ANSTF 2007)
As resources permit, the Animal and Plant Health Inspection Service (APHIS) and the Fish and Wildlife Service (FWS) will dedicate additional human and financial resources to strengthening inspection services at ports of entry. (Item 13)

By December 2003, the National Invasive Species Council (NISC) will develop a fair, feasible, and riskbased comprehensive screening system for evaluating first-time intentionally introduced non-native species. (Item 14)

By 2006, relevant Federal agencies will develop modifications to the screening system or other comparable management measures (e.g., codes of conduct, pre-clearance or compliance agreements) to formulate realistic and fair phase-in evaluation of those intentional introductions currently moving into the US. (Item 15)

Relevant Federal agencies will take the following steps to interdict pathways that are recognized as significant sources for the unintentional introduction on invasive species: (a) sponsor research to develop new technologies for ballast water management; (b) issue standards for approval of ballast water management technologies; and (c) issue additional regulations to further reduce the risk of species introductions via solid wood packaging materials. (Item 16)

By January 2002, NISC will implement a process for identifying high priority invasive species that are likely to be introduced unintentionally and for which effective mitigation tools are needed. (Item 17)

By June 2001, NISC will outline a plan for a campaign that will encourage US travelers to voluntarily reduce the risk of spreading invasive species overseas. (Item 18)

By December 2002, NISC will develop a risk assessment program for intentional and accidental introduction of non-native species through US international assistance programs and encourage other countries and international organizations to do the same. (Item 19)

By January 2003, NISC will implement a system for evaluating invasive species pathways and will issue a report identifying, describing in reasonable detail, and ranking those pathways that it believes the most significant. (Item 20)

Facilitate the development and use of science based risk assessments and other decision tools to determine risks associated with the movements of potentially invasive aquatic species and the methods to prevent and mitigate those risks. Including: (a) update the ANSTF "Generic Nonindigenous Aquatic Organisms Risk Analysis Review Process" and (b) facilitate coordinated research to develop species invasion-risk forecast tools and approaches on a pathway and source-recipient ecosystem basis.

Identify priority pathways for the introduction of harmful aquatic species into waters of the US and coordinate specific actions to reduce the likelihood of introduction of harmful nonindigenous aquatic species via these pathways. Including efforts to: (a) continue the development and testing of pathways ranking tools in conjunction with the National Invasive Species Council (NISC)/Invasive Species Advisory Committee and (b) develop and maintain a priority list of invasive pathways.

Investigate the feasibility and mechanisms for interdicting, interrupting, or minimizing priority pathways. Including: (a) take steps to interdict specific pathways; (b) encourage coordinated research to develop species invasion-risk forecast tools and approaches on a pathway and source-recipient ecosystem basis; (c) seek to establish a national integrated database of species-specific information based on the outcome of species invasion-risk forecast analyses; (d) support development, testing, and approval of ballast water treatment technologies; and (e) support completion of a permanent barrier on the Chicago Sanitary and Ship canal and analysis of barrier options on other interconnecting waterways.

Note: "Nonindigenous species" equates to "non-native species" as applied herein

\section{Existing propagule pressure-based policies}

In a limited way, the US government is already applying a "propagule pressure approach" (although different terminology is applied, depending on the sector) in a variety of prevention policy contexts aimed at minimizing the impact of harmful organisms. The goal of some of these policies is to prevent entry of invasive species propagules to the US (i.e., eliminate the propagule pool), while others are intended to reduce the spread of the propagules of harmful organisms (native or nonnative) that are already 
Table 2 International conventions and organizations outlining measures for improved invasive species prevention strategies

\begin{tabular}{ll}
\hline Convention or organization & Example documents and decisions \\
\hline $\begin{array}{l}\text { Commission for Environmental } \\
\text { Cooperation (CEC) }\end{array}$ & CEC (2002). http://www.cec.org/files/PDF/BIODIVERSITY/225-0305_en.pdf \\
$\begin{array}{l}\text { Convention on Biological } \\
\text { Diversity (CBD) }\end{array}$ & CBD (2002). http://www.cbd.int/decisions/cop-06.shtml?m=cop-06 \\
$\begin{array}{l}\text { International Plant Protection } \\
\text { Convention (IPPC) }\end{array}$ & FAO (Food and Agriculture Organization 2001). http://www.ippc.int \\
$\begin{array}{l}\text { IUCN_The World Conservation } \\
\text { Union (IUCN) }\end{array}$ & $\begin{array}{c}\text { ISSG (Invasive Species Specialist Group 2001). } \\
\text { http://www.iucn.org/themes/ssc/publications/policy/invasivesEng.htm }\end{array}$ \\
$\begin{array}{l}\text { North American Plant Protection } \\
\text { Convention (NAPPO) }\end{array}$ & NAPPO (1993). See also recent NAPPO Panel Report, 2007: \\
$\begin{array}{l}\text { Ramsar Convention on Wetlands } \\
\text { hamsar) }\end{array}$ & Ramsar Convention on Wetlands (2003). http://www.ramsar.org/res/key_res_viii_18_e.htm \\
$\begin{array}{l}\text { The Global Invasive Species } \\
\text { Programme (GISP) }\end{array}$ & McNeely et al. (2001). http://www.gisp.org/publications/brochures/index.asp \\
\hline
\end{tabular}

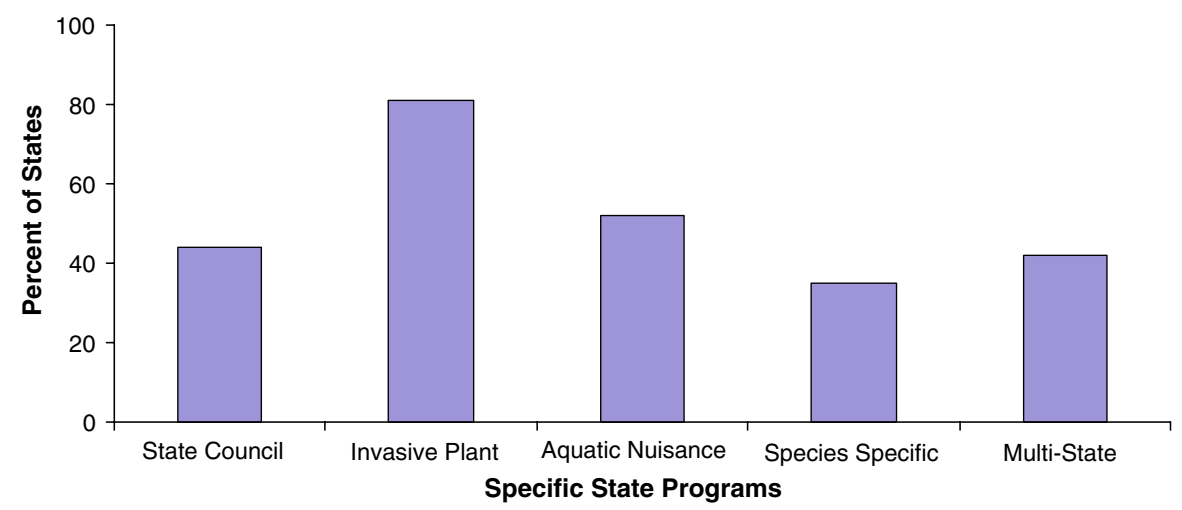

Fig. 1 State Invasive Species Programs. An increasing number of US states and territories have invasive species management plans. Rather than targeting prevention issues explicitly, they offer comprehensive approaches to invasive species prevention and management. The figure above

present within the US (i.e., minimize propagule pressure at novel sites of introduction). Recognition by policy makers and regulators that some existing US invasive species prevention policies already incorporate propagule pressure principles is likely to increase support for comprehensive prevention measures explicitly in keeping with propagule pressure science. Examples of existing policies are shown below.

\section{Zoonotic disease}

The Centers for Disease Control (CDC) prohibits importation or requires special permits for a summarizes the topical focus areas of states (plus the District of Columbia and Guam) that have councils and programs addressing invasive species (source: National Invasive Species Council)

wide-range of animal species that can transmit potentially fatal diseases (i.e., pathogen propagules) to humans. For example, CDC prohibits the import of monkeys and other nonhuman primates as pets due to concerns that they might carry diseases such as monkeypox, yellow fever, Marburg/Ebola disease, and tuberculosis (CDC 2003).

\section{Seed contamination}

Seed contamination occurs when seeds of an undesirable plant species (usually a "weed") are mixed with seeds collected and package for commercial 
(e.g., agriculture or horticulture) application. If not culled, the undesired seeds might be inadvertently planted and impact production capacity, as well as the natural environment. Federal regulations limit the number of undesirable plant seeds (i.e., propagules) that can be found per number of desired plant seeds (USDA 1939).

\section{Asian gypsy moth exclusion}

The Asian gypsy moth (Lymantria dispar) is a serious pest of deciduous trees. Although the US Department of Agriculture's Animal and Plant Health Inspection Service (APHIS) does not have a regulation prohibiting the entry of vessels that are high risk for $L$. dispar infestation, its Plant Pest and Quarantine (PPQ) division has requested that the shipping industry not bring ships into US ports that have been in Far East Russian ports between July 15 and September 30 of the previous year or high-risk Japanese ports during the high-risk hatching period (i.e., when the propagule number of $L$. dispar is likely to be highest). Under the Plant Protection Act, the Department of Homeland Security's Customs and Border Protection (DHS-CBP) service can order ships to leave US waters if Asian gypsy moths are found (USDA 2006).

\section{Ballast water}

In 2004, the US Coast Guard established a mandatory ballast water management program for all vessels equipped with ballast water tanks that enter or operate within US waters (Federal Register 2004). The intent of these measures is to eliminate the introduction of invasive marine organisms (i.e., propagules of various marine species) into US waters via the release of "organism contaminated" ballast water, thereby implementing the provisions of the Nonindigenous Aquatic Nuisance Prevention and Control Act of 1990 (as amended by the National Invasive Species Act of 1996).

\section{Wood packaging material}

APHIS restricts the importation of many types of wooden packaging materials, such as pallets, crates, boxes, and dunnage because they can serve as pathways for the introduction of a wide variety of invasive species that threaten agriculture and forest resources. APHIS regulations (as amended in 2005) are consistent with International Plant Protection Convention (IPPC) standards and require the wood packaging material to be treated (according to specific guidelines) prior to shipment to the US, as well as marked with (1) a code indicating the type of treatment used, (2) the IPPC logo, (3) the two-letter International Organization for Standardization (ISO) code for the country that conducted the treatment, and (4) a unique number assigned by the exporting country's plant protection organization (APHIS 2006). Unfortunately, due to fraudulent practices and/or the failure of the treatment methods to effectively kill all associated organisms, these regulations have not been as effective as hoped (Reaser and Waugh 2007). Thus, although the propagule pressure of wood-boring arthopods and some other species may be reduced by these measures, it has not been eliminated.

Firewood regulations

The relocation of firewood (frequently by hunters and other outdoor recreationists) can serve as a pathway for the movement of forest pests, such as the emerald ash borer (Agrilus planipennis) and Asian long-horned beetle (Anoplophora glabripennis). APHIS and some affected states have enacted infected-area quarantines and bans on the movement of firewood and other wood products in an attempt to limit the spread of these highly destructive invasives (i.e., the propagules of potentially harmful arthopods) (e.g., see http://www. ohioagriculture.gov/eab/plnt-eab-regulations.stm).

Aquatic invasive species

The 100th Meridian Initiative (see http://www. 100thmeridian.org/), Stop Aquatic Hitchhikers (see http://www.protectyourwaters.net/), and Habitattitude $^{\text {TM }}$ (see http://www.pijac.org/habitattitude) are campaigns designed by the Federal government and its partners (including private industries, state agencies, tribes and a wide variety of stakeholders) that promote voluntary "best practice" measures to 
prevent the introduction and spread of invasive species within the US. The first two campaigns encourage boaters, fisherman, and other water recreationists to take actions to prevent the movement of hitchhiking aquatic plants and other organisms among water bodies, while the third promotes responsible pet ownership and provides alternatives to the release of unwanted pets. Although not explicitly described in these terms, these programs ultimately aim to reduce the propagule pressure associated with a wide range of species.

\section{Policy gaps}

The above examples might give the impression that US policy is already well-aligned with propagule pressure principles. However, there are many instances in which the US has developed and is implementing policies that are inconsistent with the science of propagule pressure. Examples are given below.

\section{Cargo inspections}

The Department of Homeland Security's Customs and Border Protection Service (DHS-CBP) is charged with agriculture quarantine inspection, while APHIS determines the ideal methods of inspection and which species are considered quarantine pests (i.e., nonnative species already known to be harmful that are to be reported to APHIS and possibly require immediate action, such as fumigation or re-export). CBP agriculture specialists (and to a lesser degree CBP officers) visually inspect a percentage (varying among ports and commodity type) of imported commodities and their conveyances specifically for quarantine pests, while generally bypassing other organisms (e.g., all spiders) (Reaser and Waugh 2007). If an inspector opens a container and finds 12 arthropods of various species in the doorway, but none of the species are considered quarantine pests, the shipment is likely to resealed and released for distribution. Likewise, if an inspector opens a container and finds a single arthropod that is a quarantine pest, the container is likely to be resealed and treated in an appropriate manner (Reaser, personal observation). The basic rules of probability suggest that the greater the number and diversity of "hitchhikers" (propagules) in a container or on a commodity, the greater the likelihood is that one or more of those organisms will be invasive; previously unknown invasive organisms may be present and/or quarantine pests may be present but not readily detected. The current APHIS inspection policy thus enables the repeated entry of a wide diversity of undocumented organisms (propagules) of varying number.

\section{Port infestations}

Occasionally, nonnative hitchhiking organisms infest US ports of entry. If these species are not considered quarantine pests by APHIS, there is little the CBP staff can do to prevent further spread via commodities and conveyances leaving the port (Reaser and Waugh 2007). For example, the Port of Houston and surrounding areas in Harris County, Texas are currently being invaded by a type of tramp ant (Paratrechina sp.) that is attracted to and destroys electrical circuitry (Holden 2006; Reaser 2006). Researchers in the area believe that the ant may already be responsible for millions of dollars in property damage and extermination costs, the Port of Houston's radiation detection equipment has been compromised, and staff at the National Aeronautic and Space Administration (NASA) are concerned about the space program's security (Reaser and Waugh 2007). Although the ant has yet to be identified to species, APHIS considers it non-reportable and non-actionable due to its morphological similarity to other ants listed as non-reportable/nonactionable (Colpetzer 2005), and because the ant has yet to be documented as having the predicted, negative impact on wildlife, the US Fish and Wildlife Service (USFWS) does not have the authority to enact eradication and control measures (Reaser and Waugh 2007). Policies that reflected propagule pressure science would encourage and enable eradication of infesting organisms before they could be distributed widely and cause harm to a diversity of sectors.

Prior introductions

Although APHIS employs inspections and regulates plant pests (generally referred to as quarantine pests 
Table 3 Examples of opportunities for implementing propagule pressure-based policies

Pathway/vector $\quad \begin{aligned} & \text { Major types of invasives (i.e., propagules } \\ & \text { of concern) }\end{aligned}$

Import and within country movement

Solid wood packaging materials

Seaweed for bait and seafood packaging (provides moisture)

Tires

Seeds

Military vehicles and equipment

Used cars and other vehicular equipment (e.g., farm equipment)

Clay tiles (for roofing, flooring, etc.)

Within country movement

Railways

Utility line maintenance

Tourist vehicles

Field equipment

Recreational equipment
Pathogens and insects that impact forests and wood product industries Note: Use of wood products for this purpose can also result in losses of economically and ecologically valuable timber

Wide variety of marine biota that cause losses of Use damp recycled paper biodiversity and impact infrastructure

Mosquitoes that carry pathogens that transmit human and/or animal diseases

Invasive plants can outcompete native plants and non-invasive forage species. They may have indirect impacts on wildlife, especially pollinators and herbivore populations. Some species are known to alter water and fire cycles

Seeds and other plant propagative material, insects, insect eggs, and other organisms can be lodged in or on vehicles, equipment, and supplies

Seeds and other plant propagative material, insects, insect eggs, and other organisms can be lodged in or on these vehicles

Snails that can carry human and/or animal diseases, seeds, molds, insects, insect eggs, and other organisms can inhabit tiles, pallets, and shipping containers

Seeds and other plant propagative material, invertebrates, and likely rodents and occasional larger vertebrates

Seeds and other plant propagative material

Seeds and other plant propagative material, pathogens, and soil containing such, especially when at natural areas (e.g., national parks)

Seeds and other plant propagative material, pathogens, mollusks and other small animals (esp. in aquatic and marine environments)

Various, depending on ecosystem (e.g., the chytrid fungus (Batrachochytrium dendrobatidis) causing amphibian die-offs in freshwater wetlands)
Use materials made of recycled plastics, steam clean after use, and storage in sealed environment

Store dry and steam clean prior to shipping or chip prior to transport if not needed intact

Label all packages with scientific and common names so they can be checked against locally-relevant lists of invasive alien species

Steam clean vehicles and equipment and inspect all property before return to country of origin

Steam clean all undercarriages and inspect interiors

Steam clean tiles, pallets, and shipping containers immediately before shipment and store in sealed containers

Establish routine inspection, "washdown" (e.g., similar to those used by the military), and trapping protocols

Establish routine "washdown" protocols

Establish cleaning stations for vehicles and shoes at points of entry and exit

Designate equipment for us in specific sites and/or design and enact equipment cleaning protocols

Limit recreational activity at infested sites and/or post information providing information on preventive measures (e.g., cleaning recreational equipment)

Note: Adapted from Reaser et al. (2004)

and assigned "reportable" and typically "actionable" status), actions intended to keep plant pests from entering the US, inevitably some do get through. If these quarantine pests locally establish in the US in such numbers that agencies (often at the state level) cannot eradicate or control them, APHIS may no longer consider them "actionable," and in some cases no longer "reportable" or "actionable." 
Table 4 Variables influencing propagule pressure

\begin{tabular}{|c|c|}
\hline Variables & Considerations \\
\hline \multicolumn{2}{|l|}{ Socio-economic } \\
\hline Stakeholders & $\begin{array}{l}\text { Who are the relevant stakeholders and what is their economic and political investment in the } \\
\text { commodities or services involved? }\end{array}$ \\
\hline Compliance & $\begin{array}{l}\text { What it will take (financially, technically, politically, etc.) to ensure compliance? Consider what } \\
\text { incentives and/disincentives are likely to motivate compliance }\end{array}$ \\
\hline Impacts & $\begin{array}{l}\text { What environmental impacts are anticipated and how are the public and private interest groups } \\
\text { (e.g., animal rights) likely to respond? }\end{array}$ \\
\hline Implementation & $\begin{array}{l}\text { Who will implement the measures (e.g., governments, the private sector, the public) and how often } \\
\text { and for how long should implementation occur? }\end{array}$ \\
\hline Measure type & Are mandatory or voluntary measures (or some combination thereof) more like to be effective? \\
\hline Feasibility & Are the measures technically and fiscally feasible to implementing agents? \\
\hline Communication & How can the measures be effectively communicated to the stakeholders? \\
\hline \multicolumn{2}{|l|}{ Ecological } \\
\hline Mode (vector) & $\begin{array}{l}\text { (a) What amount and diversity of propagule types (species and life stages) are transportable? (b) } \\
\text { How detectable are the propagules to transporters and inspectors? }\end{array}$ \\
\hline Frequency & How often does transport occur, especially to same location? \\
\hline Time of year & $\begin{array}{l}\text { What is the diversity and number of potential invasives and their vagility during specific seasons } \\
\text { (e.g., period of emergence of winged-insects)? }\end{array}$ \\
\hline Time of day cargo loaded & $\begin{array}{l}\text { What is the diversity and number of potential invasives and their vagility within a 24-hour cycle } \\
\text { (e.g., arthopods attracted to lights when containers loaded at night)? }\end{array}$ \\
\hline Point of origin & Is the location within the native or already introduced range of potential invasive species? \\
\hline Duration of transport & $\begin{array}{l}\text { What is the length of transport time? The less the transport time, the better the condition of the } \\
\text { propagule upon arrival }\end{array}$ \\
\hline Transport environment & $\begin{array}{l}\text { What are the environmental conditions (e.g., temperature and moisture levels) that the propagule } \\
\text { experiences during transport? }\end{array}$ \\
\hline
\end{tabular}

Fundamentally, that means that these organisms have the same entry status as non-pests (Reaser and Waugh 2007). Studies of propagule pressure dynamics, particularly with regard to the genetic composition of propagule populations) strongly suggest that APHIS' policy needs to be reconsidered. An increasing number of propagules is likely to correspond to an increase in genetic diversity and the likelihood that the species could establish in a broader range of habitats as well as cause a wider ranger and perhaps intensity of impacts (Lockwood et al. 2005; Roman 2006; Meyerson and Mooney 2007).

There are also readily apparent opportunities for enacting propagule pressure-based measures to fill current gaps in invasive species prevention and control at national, state, and local levels (Table 3). At the import level, these measures aim to eliminate the overall pool of propagules. At the domestic level, the goal is to minimize propagule pressure at novel sites of introduction.

\section{Policy implementation}

Ideally, relevant agencies take a number of risk-based ecological variables into consideration when designing invasive species policies and regulations. However, they also must consider the socio-economic and political context in which these measures are to be applied. A list of socio-economic and ecological variables particularly relevant to propagule pressure-based policy development can be found in Table 4. These variables are likely to change over time, and thus policies need to be flexible enough to accommodate changes in technologies, political will (which largely influences financial resource availability), the market place, and even biological parameters influenced by changing climate patterns. For example, the Coast Guard has had to rely on moderately-successful ballast water exchange as a preventative measure because the technologies (Federal Register 2004) to fully treat ballast water 
are not yet technically and economically feasible to implement on all vessels.

In addition to the above variables, propagule pressure-based policies necessitate one further consideration: threshold determination, the pool of propagules that is acceptable for entry into the US and/or propagule pressure to a specific locale. While " 0 " propagule pressure is attractive ideologically and ecologically, it is unlikely to be feasible in most cases. Technically, it may not be achievable. For example, preventing contamination of agricultural seeds is nearly impossible even though better machines are constantly helping to reduce the number of foreign seeds gathered. And although bans on the import of certain living commodities might be politically feasible in some cases (e.g., the pet industry supported an import ban of the Gambian pouch rat (Cricetomys gambianus; Marshall Meyers, personal communication), individuals who strongly desire the commodities are likely to find an illegal means to obtain them.

Thus, policy makers and the public need to accept that some propagules will enter and/or be distributed within the US and that the actual propagule pressure is likely to vary with time and location, but be undeterminable at the point of US entry because (1) the number of hitchhikers is unknown and (2) only a fraction of the living commodities imported will be introduced into the natural environment. Consequently, investments in early detection and rapid response programs are warranted and policies need to take an adaptive management approach so that when propagules are detected, better means of limiting them can be evaluated and enacted. For example, USDA is now accepting plastic pallets for the shipments of commodities that initially arrived on pest infested wood pallets (Reaser, personal observation). If the plastic pallets prove to reduce propagule pressure, they will ideally become the transport standard.

Policy makers have two additional options for implementing propagule pressure-based policies.

Option 1. Management of unintentional introductions along specific importation pathways. Depending on the mode of transport, prevention and interception measures would be put in place to limit the potential movement of any hitchhiking organisms (e.g., Table 3). In theory, propagules of a wide range of intercepted species would be treated (e.g., via chemical, cold, or heat treatment) on the basis of number rather than just species identity. Thus introductions of species well recognized as pests and those not yet even recognized by science may be averted. However, the environmental and economic impacts of treatment need to be carefully considered in the development of all extermination policies.

Option 2. Risk-based measures for propagule limits of specific species of living commodities. Although such an approach may be attractive in theory, there are challenges to using risk-based measures to determine an actual number (beyond "0") of propagules of a specific species to permit entry and/or distribution with the US. From a scientific perspective, we would need to know the relationship between the size of the overall propagule pool and propagule pressure at potential sites of introduction. Technically, we would have to be able to carefully manage propagule flow. Furthermore, propagule pressure-based policies focused on certain intentionally introduced commodities (e.g., nursery stock and pets) are likely to be challenged on socio-economic and political grounds because they: (1) are demand driven imports (i.e., there is a public constituency in support of their entry and distribution), and (2) could foster import through relatively unregulated pathways (e.g., Internet purchase/mail delivery) and black markets. Therefore, it may be necessary to implement separate (though complementary) policies for intentional and unintentional introductions.

Whichever policy option is employed, policy makers need to proactively engage the relevant commercial industries as part of the solution. Some companies may have concerns that certain policy approaches will adversely affect competition, livelihoods, and operational procedures (which are likely to have financial implications; e.g., propagating native plants in lieu of nonnative imports) within their relevant industries. However, these and other industry representatives may also see it in their best interest to limit propagule pressure because they: (a) may themselves be at risk of invasive species impact, and (b) public perception of "good deeds" holds market place advantages.

\section{Discussion and recommendations}

Given existing trade rules under the World Trade Organization (WTO; Burgiel et al. 2006) and the lack 
of US infrastructure and political support for screening potentially invasive commodities, the application of propagule pressure-based principles is most relevant to unintentional propagule transport via major pathways (international and domestic) of biological invasion. However, where and when socio-economic and political support exists, such principles could also be readily applied to living commodities that have the potential to become invasive. For example, certain species of wildlife might be prohibited due to zoonotic disease risks and, at the domestic level, garden supply centers might sell only nonnative plants that have passed a scientifically-based risk analysis and are appropriately labeled, as well as those that are native to the local area. Both of these approaches aim to reduce propagule pressure by reducing the overall number of propagules available (i.e., the number of straws in the pile next to the camel).

At the import level, propagule pressure-based policies could be more effectively applied to living commodities if the US adopted a general "risk analysis and listing" policy. Other countries, such as New Zealand and Australia, have instituted a 'white list' approach to the import of potentially invasive species. "White lists" describe the list of those species which have been determined as low invasion risk via a scientifically-based risk analysis, and which are thus allowed entry (Ruesink et al. 1995), while "blacklists" consist of those species which have proven high-risk via the same standard risk assessment and are thus prohibited from entry (i.e., "0" propagules are permitted entry). APHIS' policy to list quarantine pests is, for example, considered a black list approach. Unfortunately, "blacklist" approaches alone have not been successful in stemming the tide of new invasions; by the time a nonnative species has amassed enough harm to be considered for blacklist status, it may be impossible to eradicate or even control (Simberloff 2000). We thus echo Simberloff (2001) in urging the US to adopt an invasive species policy that combines "white and black lists," and that prioritizes first time introductions of a species for analysis (while not ignoring those that already have propagules in distribution). Any species that was not clearly assignable to a "white" or "black" list would ideally be evaluated on a case by case basis (Ruesink 1995). We recognize that such a change in regulatory approach will take time and considerable consultation with relevant stakeholders, but believe the recommendations offered herein will help lay the groundwork for such measures.

Fundamentally and urgently, we need a paradigm shift toward propagule pressure-based policies that are built upon the following foundation of principles.

\section{Precautionary approach}

In the case of invasive species, the process of biological invasion is complex, with considerable scientific uncertainties regarding potential impacts of known, let alone unknown species. Thus, policy makers and regulators need to assume a cautious, measured approach to the propagule pressures associated with hitchhiking organisms, as well as living commodities until a thorough and credible screening is possible.

\section{Ecosystem approach}

The ecosystem approach is a strategy for the integrated management of terrestrial, aquatic, and living resources that fosters conservation and sustainable use in as equitable a manner as feasible. Currently, US policies presuppose that all propagules of a specific invasive species have an equal probability of establishment and impact (usually at the species-level) within US borders. The science of propagule pressure indicates otherwise. A more holistic approach to preventing the introduction and impacts of propagule pressure across ecosystems is needed. Furthermore, the synergist cascading effects propagule pressure can have across species or trophic levels within ecosystems needs to be considered (see http://www.cbd.int/programmes/cross-cutting/ ecosystem/default.shtml).

\section{Adaptive management}

Because "0" propagule pressure is not feasible (or at least not guaranteed), we need to increase our capacities to monitor (inspect) for invasive species propagules along various pathways of transport and introduction and ensure that policies are flexible enough to enable rapid response to unwanted introductions via policy adjustments (i.e., changes in regulatory procedures) and eradication measures. 
Risk analyses

Invasive species risk analysis models currently being employed and developed in the US (both at the species- and pathway-level) largely focus on natural history characteristics and socio-economic measures. Propagule pressure concepts could be incorporated into these models taking into consideration the genetic diversity among propagules and estimates of propagule size and number.

\section{Multi-stakeholder engagement}

It is critical that the issue of propagule pressure is effectively communicated and made relevant to stakeholder groups when policies are being developed and implemented. This approach achieves at least three things: (1) it can help minimize the vast number of entry points for propagules (imports, souvenirs, etc.) via voluntary measures, (2) assist policy makers in identifying alternative transport and packaging measures that are both effective and readily acceptable (even through regulation), and (3) builds a "constituency pressure" that is needed for public support of such policies.

\section{Steadfast political support}

Invasive species have the potential to harm the interests of all sectors of society and thus invasive species prevention policies both warrant and necessitate broad political support. Propagule pressure policies, though necessarily flexible in specific terms of application, must fundamentally extend beyond the terms of elected officials. US policy makers need to acknowledge that this type of approach is in the best interest of national biosecurity in terms of human health, the economy, and the environment.

\section{Complementary education campaigns}

Due to fiscal and political constraints, regulation alone will not minimize the US entry and transport of invasive species propagules. Educational campaigns targeted as special interest groups and designed according to social marketing principles (such as those described under Existing Propagule Pressurebased Policies) have the potential to increase awareness of the issues, reporting of introductions, compliance with regulations, and voluntary measures to reduce propagule pressure.

\section{Conclusions}

Invasive species are a negative externality of trade, travel, and transport, all factors projected to increase through globalization. Failure of the US and other governments to address the underlying causes of biological invasion and mitigate their impacts will continue to result in loss of numerous species and genetic resources, as well as undermine the human condition (e.g., via disease epidemics and economic loss). Because invasive species are exchanged through the market place they are a problem that will have to be managed in perpetuity, and with international cooperation. However, the problem need not grow as the rate, scale, and volume of traded commodities and services increase.

Propagule pressure-based policies applied to the unintentional movement of potentially harmful organisms via pathway management offer opportunities to reduce invasion risk in the context of "doing business." Relatively simple and low cost changes in the way certain commodities and services are distributed could significantly reduce propagule pressure, and ultimately the impact of a wide range of invasive species (Table 3). Where socio-economic and political support exists, propagule pressure-based policies could also be used to address living commodities that have the potential to become invasive. Policy makers and regulators thus need to pay closer attention and take concerted action to minimize the propagule pressure of invasive species into and within the US. Propagule number, size, and sources (i.e., genetic diversity) all have the potential to influence the level and diversity of invasive species impacts and thus need to be fundamental aspects of invasive species prevention policies.

In an ideal world, we wouldn't have to employ our camel to carry straw. In this day and age, however, that's just not feasible. So, in short, we need to know our camel's threshold for tolerance, under what circumstances it can and cannot withstand heavier loads (i.e., what influences risk), and act accordingly. 
The camel's back will stand a chance if given proper preventative care.

Acknowledgements This review was inspired by discussion at the workshop "The link between propagule pressure and nonnative invasion success and impacts" sponsored by the National Center for Environmental Assessment at the United States Environmental Protection Agency (EPA). We thank Joe Cavey, Chris Dionigi, Dan Kluza, Richard Orr and Lori Williams for providing background information and Erika Patenude for assistance with manuscript preparation. We appreciate the insightful comments by Jeff Frithsen, Jeff McNeely, and Michael Slimak. Many thanks to Dan Simberloff for his support and encouragement. JKR's contribution to this paper was supported by a grant from the EPA's Global Change Research Program, within the Office of Research and Development. LAM was supported by a USDA Agricultural Experiment Station grant and the University of Rhode Island College of Environmental Life Sciences. BVH was supported by an AAAS Science and Engineering Fellowship at the EPA. The research described in this paper has been funded wholly or in part by the through cooperative agreement number CR828392 with the American Association for the Advancement of Science (AAAS). The views expressed herein may not necessarily reflect the views of EPA or AAAS and no official endorsement should be inferred.

\section{References}

[APHIS] Animal Plant Health Inspection Service (2006) Implementation of wood packaging material regulation. APHIS fact sheet. http://www.aphis.usda.gov/publications/ plant_health/content/printable_version/fs_wpm5-06.pdf. Cited 19 July 2007

[ANSTF] Aquatic Nuisance Species Task Force (2007) Aquatic Nuisance Species Task Force strategic plan (2007-2012). http://www.anstaskforce.gov/plan.php. Cited 19 July 2007

Beirne BP (1975) Biological control attempts by introductions against pest insects in field in Canada. Can Entomol 107:225-236

Burgiel S, Foote G, Orellana M, Perrault A (2006) Invasive alien species and trade: integrating prevention measures and international trade rules. http://www.cleantrade.net. Cited 16 Oct 2007

Cappuccino N (2004) Allee effect in an invasive alien plant, pale swallow-wort Vincetoxicum rossicum (Asclepiadaceae). Oikos 106:3-8

[CDC] Centers for Disease Control (2003) Etiological agents, hosts, and vectors. http://www.edocket.access.gpo.gov/ cfr_2003/octqtr/42cfr71.54.htm. Cited 17 July 2007

[CEC] Commission for Environmental Cooperation (2002) Objective 2.25 Closing the pathways of aquatic invasive species across North America. North American Agenda for Action: 2003-2005; Conservation of Biodiversity. http://www.cec.org/files/PDF/BIODIVERSITY/225-0305_en.pdf. Cited 17 July 2007

[CBD] Convention on Biological Diversity (2002) Alien species that threaten ecosystems, habitats, or species. In:
Sixth conference of the parties, 7-19 April, Decision 23. http://www.cbd.int/decisions/cop-06.shtml?m=cop-06. Cited 17 July 2007

Colpetzer KE (2005) NPAG preassessment: Paratrechina (Fulva) sp. near pubens Forel, Hymoperta/Formicidae. 28 October 2005. USDA Animal Plant and Health Inspection Service, Washington, DC

Crawley MJ (1989) Chance and timing in biological invasion. In: Drake JA, Mooney HJ, Di Castri F, Groves RH, Kruger FJ, Rejmanek M, Williamson M (eds) Biological invasions: a global perspective. John Wiley, Chichester, UK, pp 407-424

D'Antonio C, Levine J, Thomsen M (2001) Ecosystem resistance to invasion and the role of propagule supply: a California perspective. J Mediterr Ecol 2:233-245

Duggan IC, Rixon CAM, MacIssac HJ (2006) Popularity and propagule pressure: determinants of introduction and establishment of aquarium fish. Biol Invasions 8:377-382

Federal Register (2004) Mandatory ballast water management program for U.S. waters. Department of Homeland Security, Coast Guard. Fed Regist 69(144):44952-44960

Federal Register (1999) Executive Order 13112: invasive species. Office of the President. Fed Regist 64(25): 6183-6186

Fine PVA (2004) The invasibility of tropical forests by exotic plants. J Trop Ecol 18:687-705

[FAO] Food and Agriculture Organization (2001) Appendix XIII: statements of the ICPMExploratory Open-ended Working Group on phytosanitary aspects of GMOs, biosafety, and invasive species. Report of the third interim commission on phytosanitary measures. Food and Agriculture Organization, Rome, Italy, 2-6 April 2001. http://www.ippc.int. Cited 17 July 2007

[GAO] Government Accountability Office (2006a) Homeland security: management and coordination problems increase the vulnerability of US agriculture to foreign pests and disease. GAO-06-644. http://www.gao.gov/cgi-bin/getrpt? GAO-06-644. Cited 17 July 2007

[GAO] Government Accountability Office (2006b) Invasive forest pests: lessons learned from a three recent infestations may aid in managing future efforts. GAO-06-353. http://www.gao.gov/cgi-bin/getrpt?GAO-06-353. Cited 17 July 2007

Green RE (1997) The influence of numbers released on the outcome of attempts to introduce exotic bird species to New Zealand. J Anim Ecol 66:25-35

Holden C (2006) Move over, fire ants. Science 313:1549

[ISSG] Invasive Species Specialist Group (2001) IUCN guidelines for the prevention of biodiversity loss caused by alien invasive species. ISSG, Species Survival Commission of IUCN - The World Conservation Union, Gland, Switzerland. http://www.iucn.org/themes/ssc/ publications/policy/invasivesEng.htm. Cited 17 July 2007

Levine JM, D'Antonio CM (2003) Forecasting biological invasions with increasing international trade. Conserv Biol 17:322-326

Lockwood JL, Cassey P, Blackburn T (2005) The role of propagule pressure in explaining species invasions. Trends Ecol Evol 20:223-228

Lonsdale WM (1999) Global patterns of plant invasions and the concept of invasibility. Ecology 80:1522-1536 
Mack RN, Simberloff D, Lonsdale WM, Evans H, Clout M, Bazzaz FA (2000) Biotic invasions: causes, epidemiology, global consequences and control. Ecol Appl 10:689-710

McCullough DG, Work T, Cavey JF, Liebhold AS, Marshall D (2006) Interceptions of nonindigenous plant pests at US ports of entry and border crossings over a 17 year period. Biol Invasions 8:611-630

McNeely JA, Mooney HA, Neville LE, Schei PJ, Waage JK (eds) (2001) Global strategy on invasive alien species. IUCN in collaboration with the Global Invasive Species Programme, Cambridge, UK

Meyerson LA, Mooney HA (2007) Invasive alien species in an era of globalization. Front Ecol Environ 5:199-208

[NISC] National Invasive Species Council (2001) National invasive species management plan. http://www. invasivespeciesinfo.gov. Cited 17 July 2007

[NPB] National Plant Board (1999) Safeguarding American plant resources: a stakeholder review of the APHIS-PPQ safeguarding system. http://www.nationalplantboard.org/ policy/safeguard.html. Cited 17 July 2007

[NAPPO] North American Plant Protection Organization (1993) International approaches to plant pest risk analysis. In: Proceedings of the APHIS/NAPPO international workshop on the identification, assessment, and management of risks due to exotic agricultural pests. Alexandria, Virginia, 23-25 October 1991. NAPPO Bulletin no. 11. North American Plant Protection Organization, Ottawa, Canada

Parker IM, Rodriguez J, Loik ME (2003) An evolutionary approach to understanding the biology of invasions: local adaptation and general-purpose genotypes in the weed Verbascum thapsus. Conserv Biol 17:59-72

Ramsar Convention on Wetlands (2003) Resolution VIII.8 on invasive species and wetlands. In: 8th meeting of the conference of the contracting parties to the convention on wetlands, Valencia, Spain, 18-26 November 2002. http://www.ramsar.org/res/key_res_viii_18_e.htm. Cited 17 July 2007

Reaser JK (2006) Case study: Paratrechina ant invasion. In: Special report to the EPA Office of International Affairs under the IUCN-led project entitled, Managing risks from the introduction of invasive species: focus on pathways linked to international trade. IUCN-World Conservation Union, Washington, DC

Reaser JK, Waugh JA (2007) Denying entry: opportunities to build capacity to prevent the introduction of invasive species and improve biosecurity at US ports. IUCN-World Conservation Union, Washington, DC

Reaser JK, Yeager BB, Phifer PR, Hancock AK, Gutierrez AT (2004) Environmental diplomacy and the global movement of invasive alien species: a U.S. perspective. In: Ruiz G, Carlton J (eds) Invasive species: vectors and management strategies. Island Press, Washington, DC, pp 362-381

Roman J (2006) Diluting the founder effect: cryptic invasions expand a marine invader's range. Proc Roy Soc Biol Sci 273:2453-2459

Roman J, Darling J (2007) Paradox lost: genetic diversity and the success of aquatic invasions. Trends Ecol Evol 22:454-464

Ruesink JL, Parker IM, Groom MJ, Kareiva PM (1995) Reducing the risks of nonindigenous species introductions: guilty until proven innocent. Bioscience 45: 465-477

Sala OE, Chapin FS III, Armesto JJ et al (2000) Global biodiversity scenarios for the year 2100. Science 287: 1770-1774

Simberloff D (1989) Which insect introductions succeed and which fail? In: Drake JA, Mooney HA, di Castri F, Groves RH, Kruger FG, Rejmánek M, Williamson M (eds) Biological invasions: a global perspective. John Wiley, Chichester, UK, pp 61-75

Simberloff D (2000) Nonindigenous species: a global threat to biodiversity and stability. In: Raven P, Williams T (eds) Nature and human society: the quest for a sustainable world. National Academy Press, Washington, DC, pp 325-336

Simberloff D (2001) Biological invasions - how are they affecting us, and what can we do about them? West N Am Nat 61:308-315

[USDA] US Department of Agriculture (1939) Federal Seed Act. US Department of Agriculture, Animal and Plant Health Inspection Service (APHIS), Washington, DC. http://www.ams.usda.gov/lsg/seed/fsa-98.pdf. Cited 25 July 2007

[USDA] US Department of Agriculture (2006) Manual for agricultural clearance. 06/2006-22. US Department of Agriculture, Plant Pest and Quarantine (PPQ), Washington, DC

Veltman CJ, Nee S, Crawley MJ (1996) Correlates of introduction success in exotic New Zealand birds. Am Nat 147:542-557

Von Holle B, Simberloff D (2005) Ecological resistance to biological invasion overwhelmed by propagule pressure. Ecology 86:3212-3218

Watson RT, the Core Writing Team (eds) (2001) Climate change 2001: synthesis report. Intergovernmental Panel on Climate Change, Geneva, Switzerland

Williamson M (1996) Biological invasions. Chapman and Hall, London 